\title{
VANDALISM IN A MANITOBA CASPIAN TERN COLONY
}

WILLIAM H. KOONZ, Department of Natural Resources, Box 14, 1495 St. James Street, Winnipeg, Manitoba. R3H OW9

On 16 June 1981, I visited several Manitoba colonial waterbird colonies on islands in southern Lake Winnipegosis. On a gravel reef off the south end of Coleman Island $\left(51^{\circ} 55^{\prime} \mathrm{N}\right.$; $\left.100^{\circ} 03^{\prime} \mathrm{W}\right)$, I found 23 bodies and 25 heads of adult Caspian Terns. At least one week was estimated to have passed since the vandalism had occurred. All bodies were some distance from their heads. Blood stains on the feathers indicated that the birds had been shot then beheaded. Since the reef is narrow and more heads than bodies were observed, it is suspected that other bodies and/or heads fell or were thrown in the water.

Although no remains of adult Doublecrested Cormorants were found, the Cormorant colony on the reef had been reduced to fewer than a dozen active nests, down from $135 .^{5}$ A significant number (100土) Cormorant nests had been destroyed, stones being on top of numerous eggs and/or young.

There were 30-40 Herring Gull nests also present on the island. Since young Herring Gulls were already out of their nests it was difficult to determine if that colony had been vandalized.

Despite the vandalism, 37 active Caspian Tern nests were recorded, appearing in an early development stage. Twenty-three contained two eggs, six contained one egg while eight were simple depressions in the lightly grassed, coarse sand. It was not determined if this represented the initial nesting attempt or renesting although no indication of previous nesting attempts were observed on the island. Coleman Island was not listed in the literature as a Caspian Tern colony site. ${ }^{6}$ Observa- tions on 16 June 1981, indicated that roughly 100 adult Caspian Terns were attracted to the site.

Vandalism by humans is not new to Manitoba's colonial nesting waterbirds. Egg gathering for food is still practised in a number of areas, especially near remote northern communities. Provincial Fisheries reports document the Province's past active programs to reduce Double-crested Cormorant numbers on Lake Winnipegosis under pressure from commercial fishermen. ${ }^{34}$ Other colonial species may provide displacement behaviour for fishermen bent on destroying supposed sources of depleted stocks of commercially valuable fishes.

The Caspian Tern is often collected by scientists, shot by curious hunters, and taken for food in parts of its wintering range. 'It is a highly vocal species which aggressively defends its colonies, a factor which may contribute to vandalism.

The Caspian Tern is considered rare in Canada according to the Committee on the Status of Endangered Wildlife in Canada. ${ }^{2}$ A number of factors contribute to the overall low numbers and erratic Canadian distribution of the species. Manitoba is considered to harbour 59 percent of the breeding Canadian population.

'LUDWIG, J.P. 1965. Biology and structure of the caspian tern (Hydroprogne caspia) population of the great lakes from 1896-1964. Bird Banding 36:217233.

${ }^{2}$ MARTIN, M. 1979. Status report on caspian tern (Sterna caspia) in Canada. Com- 
mittee on the Status of Endangered Wildlife in Canada. Canadian Wildlife Service. Ottawa, Ontario. 43pp.

${ }^{3}$ McLOED, J.A. 1943. Report on the crowduck menace on Lake Winnipegosis. Man. Dept. of Nat. Res. Fisheries Br. Wpg. $17 p p$.

${ }^{4}$ MCLOED, J.A. 1954. Continued studies on the double-crested cormorant on Lake Winnipegosis for the years 1953 and
1954. Man. Dept. of Nat. Res. Fisheries Br. Wpg. 9pp.

${ }^{5}$ VERMEER, K. 1969. The present status of double-crested cormorant colonies in Manitoba. Blue Jay 27: 217-220.

${ }^{6}$ VERMEER, K. 1970. Large colonies of caspian terns on Lake Winnipeg and Winnipegosis, 1970. Blue Jay 28:117118.

\section{AN EASTERN WOOD PEWEE NEAR BETHUNE}

CHRISTOPHER I. G. ADAM, 2636 Argyle Street, Regina, Saskatchewan. S4S OK1

On 3 July 1981, an Eastern Wood Pewee (Contopus virens) was encountered in the Qu'Appelle Valley 14 kilometres south of Bethune, Saskatchewan, by the author and Keith Neufeld, during investigations of natural areas for Saskatchewan Environment. The bird was first heard singing in late morning by the author, who immediately identified it as an Eastern Wood Pewee. The bird was approached to within $15 \mathrm{~m}$, photographed, and was observed singing for 20 minutes. The author is familiar with the song of this eastern species, having lived for several years in eastern Canada, and had in fact heard one as recently as 28 June 1981 in Manitoba.

The pewee had a pale breast with light gray sides and a yellowish wash towards the belly, a pale throat, and an orange lower mandible, in contrast to the darker Western Wood Pewee (Contopus sordidulus). The song was the typical, whistled "pee-ah-wee, pee-ahwee, pee-urr", constantly repeated. The pewee was still singing when the observers left the area around noon. The weather was hot and sunny.
Bob Luterbach of Regina had no luck finding the pewee at the same place at 0630 the next morning. The author is satisfied the location was revisited since Luterbach's description corresponded perfectly.

The pewee was found in a Manitoba Maple (Acer negundo) grove at the south end of an intermittant slough and near a gravel pit on the Qu'Appelle Indian Burial Site, an IBP (International Biological Program) area bordering the southern slope of the Qu'Appelle River. The exact location of the sighting is Sec. 2 - Twp. 19 - Rg. 24 - W2, which is approximately 45 kilometres northwest of Regina.

The bird was undoubtedly a summer visitant, probably having found its way westwards along the Qu'Appelle Valley. Belcher ${ }^{1}$ and Callin ${ }^{2}$ cite several occurrences in Saskatchewan. It is suspected as breeding regularly along the Qu'Appelle Valley as far west as Echo Lake. ${ }^{2}$ One was heard calling 11 May 1968 by A. Binnie near Flying Creek, north of Regina. ${ }^{2}$ 